Геометрические исследования срединных поверхностей

тонких оболочек

УДК 004.925.83

\title{
AUTOMATIC MODELING OF THE SURFACES OF THE EQUAL SLOPE IN AUTOCAD SYSTEM THROUGH LANGUAGE AUTOLISP
}

V.A. ROMANOVA, assistant of professor

THOMA ANAMARIYA, bachelor

Peoples' Friendship University of Russia, Moscow, Russia,

6, Miklukho-Maklaya Str., Moscow, Russia, 117198

Graphical computer modeling is a real possibility of solving problems on the formation of surfaces by a kinematic method. It is due to the presence of automated design systems, such as MathCad, Mathematika, AutoCad, etc. The advantage of the AutoCad system is the presence of the built-in language of functional AutoLisp. Having a wide range of mathematical functions and functions for drawing graphic objects, the AutoLisp language allows you to write a program for drawing shells of any complexity, in a particular case - shells of the same ramp on the elliptical plane, the surface of the involute helicoid, and then transferring the results to the AutoCAD environment. Playing objects in slow motion makes it possible to compose mini-films about the formation of surfaces. The image of graphical constructions in three-dimensional space using the AutoCAD color palette enhances the expressiveness of the image of surfaces and their elements.

The aim of the study is the possibility of modeling the surface of the equal slope ramp on an elliptical plane, carried out by its gradual drawing in a slow dynamic mode with the creation of a mini-film that allows the surface to be displayed on the monitor screen.

KEY WORDS: equal slope surface, modeling, AutoLISP, AutoCAD, shell, shaping, layer, generatrix, developable surface, elliptic plane.

Surfaces of the equal slope are used in architecture since ancient times. An example is the Greek theater (fig. 1) [1]. Currently, they are increasingly used in projects of architectural ensembles, including combinations of geometric shapes. Museum of contemporary art (Niteroi, Brazil, architect Oscar Niemeyer) (fig. 2) is one of them [2], etc.

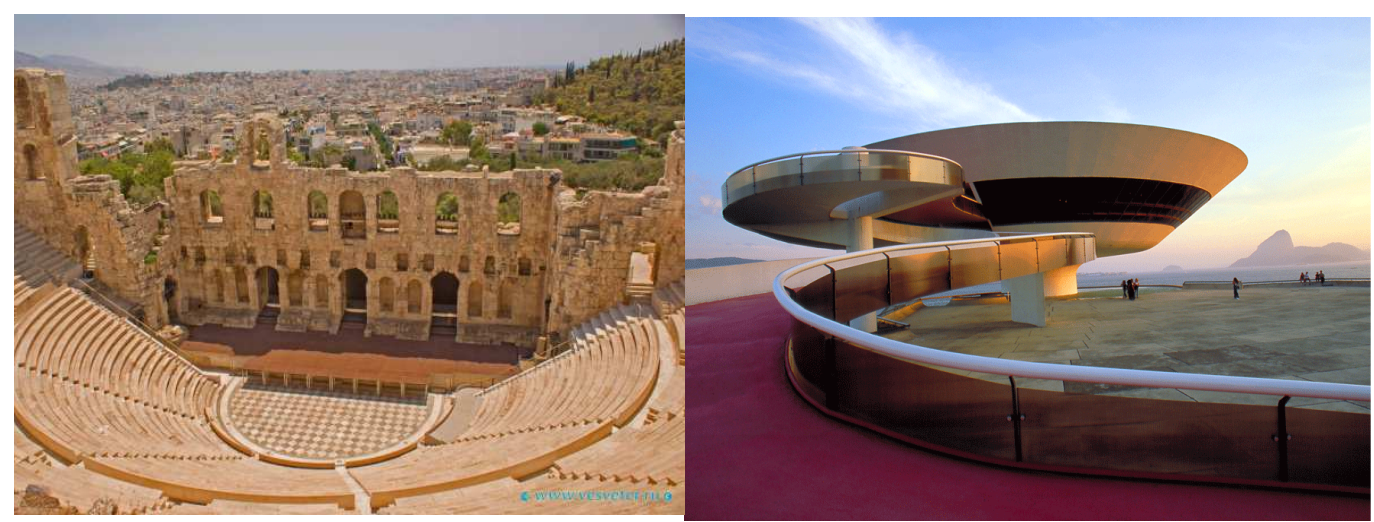

Fig. 1. Ancient Greek theatre

Fig. 2. Museum of contemporary art (Niteroi, Brazil, architect Oscar Niemeyer)

The surface of the equal slope is a ruled analytic surface having a constant angle of inclination between the rectilinear generatrix and the principal normal to the directing curve. The general theoretical basis for the formation of surfaces is given in the work of Krivoshapko S.N. and Ivanov V.N. [3]. 
In accordance with the definition given above, the surfaces of the equal slope are formed by a rectilinear generatrix, which in all positions has a constant angle of inclination $\alpha$ with the principal normals $n_{1}, n_{2}, n_{3}, \ldots, n_{k}$ to the $m$ curve. If the directing curve is a plane line, for example, an ellipse, the linear generators lie in the planes $\Pi_{1}, \Pi_{2}, \Pi_{3}, \ldots, \Pi_{k}$, normal to this curve (fig. 3 ).

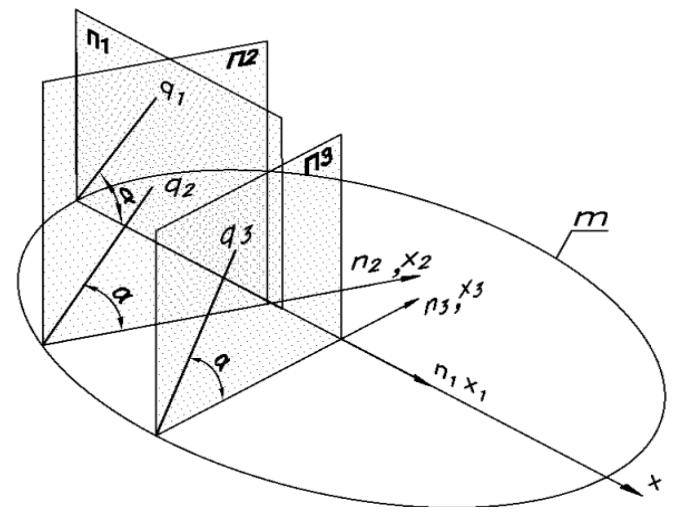

Fig. 3. The forming $q_{1}, q_{2}, q_{3}$ are in the planes $\Pi_{1}, \Pi_{2}, \Pi_{3}$ are located along the normals to the $m$ guide.

From the definition, the possibility of forming a surface of the equal slope on an elliptical plane by a kinematic method also follows.

Elements of the surface are the ellipse $q$ - the directing line and the straight line $m$ - the generator. The initial position of the surface elements is shown in Fig. 4.

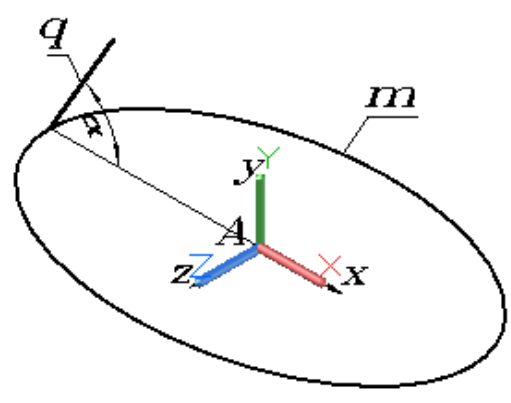

Fig. 4. The initial position of the surface elements
The most suitable for forming the surface in the AutoCad system is the Loft function. As sections it is necessary to take the positions of the generator as it moves along the ellipse. Moving the generator is performed by the Move function.

To satisfy the condition of constancy of the angle between the generating straight line and the normal to the ellipse, it is necessary to set the coordinate system to the current point on the elliptic curve at each step of the construction and to direct the $\mathrm{x}$ axis along the normal in this curve. In order to establish the $\mathrm{x}$-axis along the normal to the guide, the value of the derivative

$y^{\prime}(x)$ from the elliptic function and the angle $\gamma$ between the tangent to the curve and the $\mathrm{x}$-axis: $\gamma=\operatorname{arctg} \mathrm{y}^{\prime}$, and then the angle $\beta$ between the $\mathrm{x}$-axis and the normal to the curve: $\beta=\gamma+90^{\circ}$.

To form the surface the complex of programs has been developed, including user functions Sk10.1sp, Formsurface.lsp, etc. The initial data for constructing the surface are: the large and small semi-axes of the ellipse $a, b$, the slope angle $\alpha$ of the forming straight line to the normal $n_{i}$, the length of the forming line - Lobr.

Algorithm of the program for the formation of surface compartments 1. Input of initial data is performed from the command line at the request of the program. The function Getreal is used.

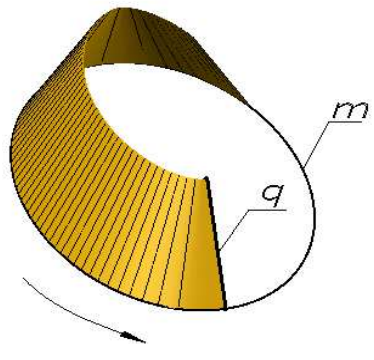

Fig. 5. The formation of surface

1. An isometric view of NWiso is established. 
2. An ellipse is constructed using the user-defined Elip function. The origin is at the intersection of the axes of the ellipse.

3. An empty selection is created for the forming lines of surfaces. The function (setq ssr1 '()).

4. The initial generator is constructed from two points: pt1 and pte. The point pt1 is given on the contour of the ellipse at $\varphi=0$, where $\varphi$ is the angle between the radius vector of the ellipse point and the $\mathrm{x}$ axis. The point pte is defined in polar coordinates: (setq pte (polar pt1 (- pi alfar) lobr)).

The construction of the generatrix is performed by the function: (command "pline" pt1 pte "").

The generating line is assigned the identifier en1, which allows you to enter it into the selection ssr1.

5. To calculate the coordinates of points of an ellipse and the derivative of an elliptic function, two user functions are created: El-pt, El1-pt.

6. To construct the surface compartments, a loop with parameters i $(1 \leq i \leq$ 71) and $\varphi$.

The parameter $i$ is required to form the name of the layer, the parameter $\varphi$ is used to construct the generating lines.

The following operations are performed in the loop:

- Create a layer name that corresponds to the i parameter and set it to the current one:

(Setq nsloy (strcat "vent" (itoa i)))

(Command "layer" "s" nsloy "').

- Transfer of the coordinate axes to the ellipse point pt2, corresponding to the angle $\varphi$, determined by the relation $\varphi=\varphi+\Delta \varphi$.

- Two user functions Usk1 and Usk2 are created to orient the coordinate axes along the normal to the ellipse. The angle $\gamma$ needed to rotate the coordinate axes around the $\mathrm{z}$ axis is determined using functions

$$
\begin{gathered}
(\text { Setq y11 (/ b }(* a-1.0(/(\sin \mathrm{fi})(\cos \mathrm{fi}))))) \\
(\text { Setq gamma }(\operatorname{atan} \mathrm{y} 11)) .
\end{gathered}
$$

A subsequent rotation of the coordinate system about the $\mathrm{x}$ axis through an angle $\pm 90^{\circ}$ around the $\mathrm{y}$ axis achieves the setting of the coordinate axes so that the $\mathrm{x}$ axis is directed along the normal to the ellipse.

- Drawing generating lines is performed by the function

$$
\text { (Command "pline" '(0 0) (polar ' (0 0) alfar lobr) ""). }
$$

- The Loft and Foreach functions work together to form the surface compartments.

At the end of the cycle, a Skat-bl block is created, containing the surface compartments and the forming lines.

To visualize the process of surface formation, a user function Sk11.lsp is created, which includes the function Form-surface.lsp, which visualizes the process of surface formation by "unfreezing" the layers with the compartments contained in the Skat-bl block.

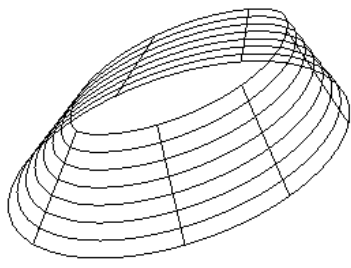

Fig. 6. Surface skeleton

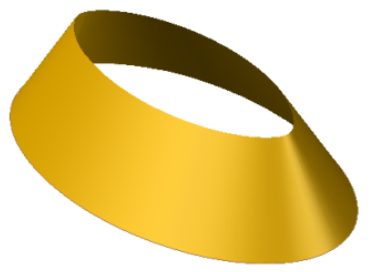

Fig. 7. Surface of the same slope

Fig. 5 shows the process of surface formation, the surface skeleton is in Fig. 6, the surface of the same slope is represented in Fig. 7. 
The code for the Form-surface.lsp function is given below:

(Defun form-surface $(\mathrm{k})$

(Repeat k

(Setq nsloyi (strcat "vent" (itoa i)))

(Command "layer" "thaw" nsloyi "")

(Command "erase" s1 "")

(Setq s2 (ssget "x" (list (cons 8 (substr nsloyi 16$))))$ )

(Setq s1 s2)

(Command "delay" 300)

(Setq i (+ i 1))

))

The developable evolvent helicoid is formed by the motion of a straight forming line- $q$, which is in all positions the tangent to the cylindrical helical line - the cuspidal edge of the surface, parallel to the guide cone [4]. The evolvent of the circle of the lower base of the cylinder is the guiding line $\mathrm{m}$ (fig.8).

The projection of the formation line in all positions on one side is a tangent of the circumference of the cylinder, the other normal to the guide line $m$. Consequently, the angle between the generator and its projection is the angle between the generatrix and the principal normal to the directing curve, so the evolvent helicoid belong to the surface of the same slope (fig. 8).

Let us consider the formation of an evolvent helicoid by the motion of a rectilinear forming line $q$ on two helical lines, one of which lies on a cylinder of radius $r$ and is called the cuspidal edge, the forming line $q$ at all positions is tangent to the line $m$ and forms an angle $\alpha$ with the horizontal plane. The second line $n$ (Fig. 9) is the guide. The radius of the cylinder for helix $n$ is BD. To construct the surface of a helicoid, the length of the forming line and the angle $\alpha$ of its inclination to the horizontal plane are given.

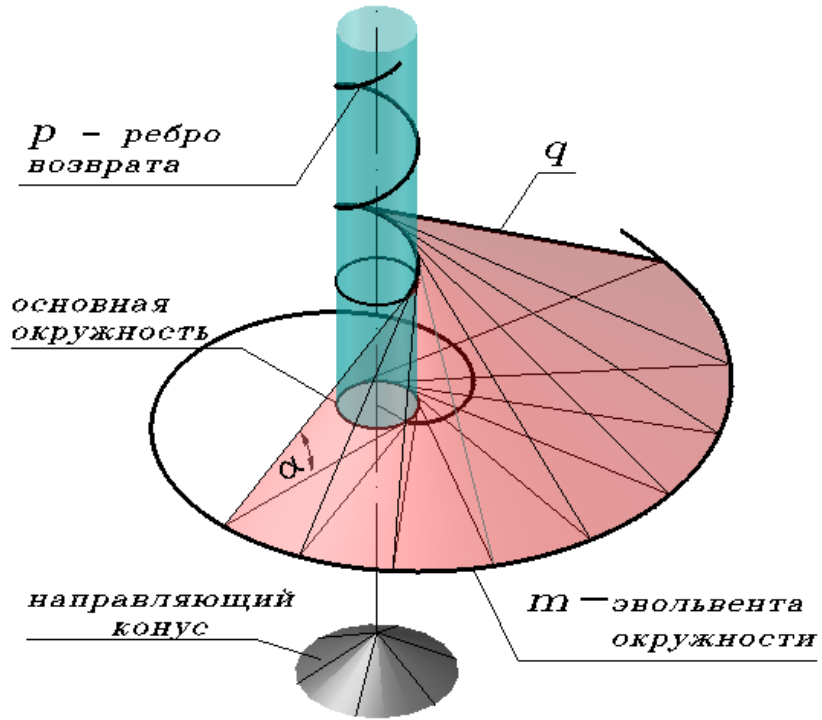

Fig. 8. Evolvent helicoid is the surface of equal slope

Fig. 9 shows the initial position of the surface elements. The movement of the generating line includes a rotational motion about the axis of the cylinder and the translational motion along the generatrix of the cylinder.

The helixes $m$ and $n$ are drawn by the user function Gelisa $(r)$, where $r$ is the radius of the cylinder. 
The surface of the helicoid is formed in the AutoCAD system through a program in the language of AutoLISP [5].

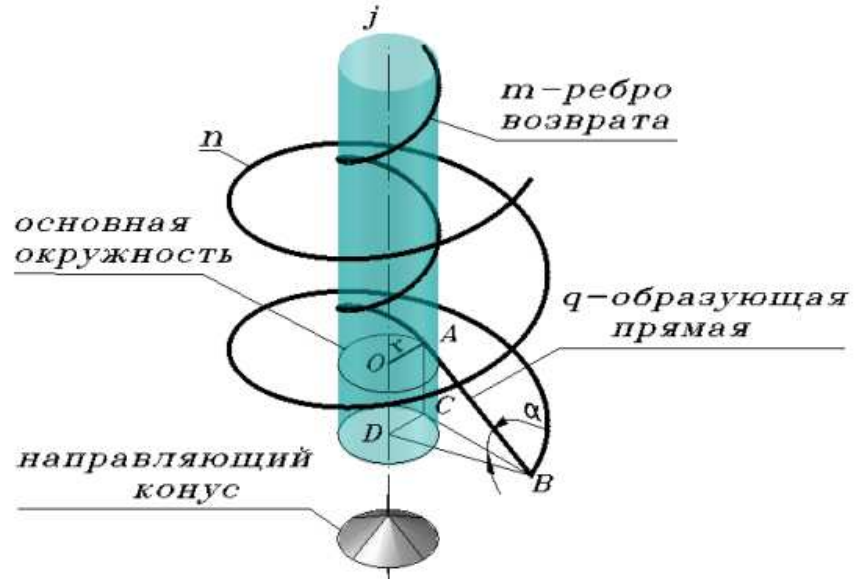

Fig. 9. Initial position of surface elements

The generating lines are formed in a cycle with the parameter $\varphi$ - the angle of rotation of the radius of the basic circle. At each step of the cycle, the point A rotates by an angle $\mathrm{d} \varphi$ and moves upward by a distance $d s$. From the point $\mathrm{A}$ for each value of the angle $\varphi$, the generating line AB is drawn at a given slope angle $\alpha$ to the segment DB. The names of the generators are entered in the SSR list, the use of which by the AutoLISP functions Foreach and Loft allows to form the surface and its compartments.

The surface can be constructed instantly at the end of the cycle by the Loft function or gradually in a cycle by successively drawing the surface compartments. In the second case, the process of formation of a surface along an array of generating lines is observed on the screen. In Fig. 10 shows the surface of the evolvent helicoid in the process of its formation.

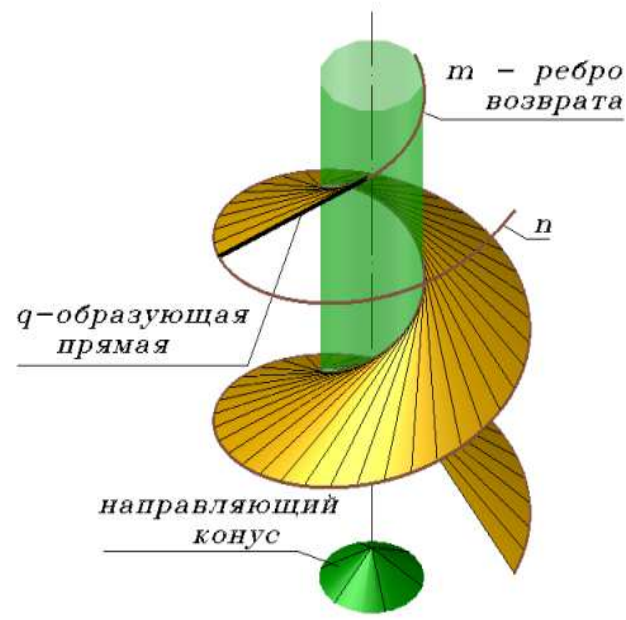

Fig. 10. Surface of the evolvent helicoid during formation

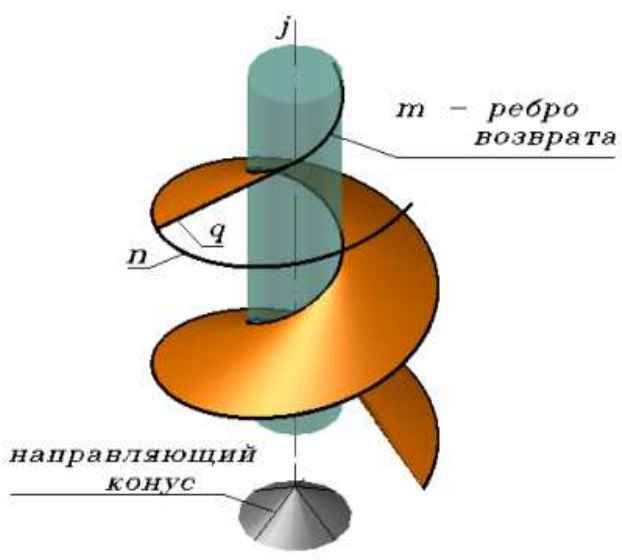

Fig. 11. Formation of the surface by the method of "thawing" layers.

If during the formation of the surface each formation line and corresponding compartment are placed in the layer assigned to them, then at the end of the cycle a block is created that includes all the surface compartments and formation lines. 
Visualization of the process of surface formation is provided by the user-defined function Form-surface.lsp. In this case, the surface is formed after the forming line, moving along the guide $\mathrm{n}$. (Fig. 11).

Thus, the simulation of the surface of the same slope was made possible in $\mathrm{Au}-$ toCAD thanks to programs written in AutoLisp.

The visualization of the process of formation of cyclic surfaces with variable radius of generatrix circles or of umbrella-type and umbrella surfaces with radial damping waves in the central point given in the works [6], [7].

(C) Romanova V.A., Thoma Anamariya, 2017

$$
\text { References }
$$

1. Ancient Greek theatre. By Vlad. URL: https://www.thinglink.com/scene/471251280036102146

2. Museum of contemporary art (Niteroi, Brazil, architect Oscar Niemeyer)]. URL: https://www.adme.ru/tvorchestvo-dizajn/shedevry-sovremennoj-arhitektury566805/?page=3\#image27349615

3. Krivoshapko, S.N., Ivanov, V.N. (2015). Encyclopedia of Analytical Surfaces. Springer International Publishing Switzerland, $752 \mathrm{p}$.

4. Krivoshapko S.N. (1999). Geometry and strength of general helicoidal shells. Applied Mechanics Reviews, Vol.52, No 5. 161-175.

5. Ivanov, V.N., Romanova, V.A. (2016). Structural Forms of Spatial Structures. Visualization of Surfaces in the Systems MathCad, AutoCad, Moscow: Izd-vo ASV.410 (in Russian).

6. Romanova, V.A. (2016). The formation of cyclic surfaces with variable radius of generatrix circles in AutoCAD. Structural Mechanics of Engineering Constructions and Buildings, No 3, 20-24 (in Russian).

7. Romanova, V.A. (2015). Visualization of forming of umbrella-type and umbrella surfaces with radial damping waves in the central point, Structural Mechanics of Engineering Constructions and Buildings, No 3, 4-8 (in Russian).

Article history: Received: March 13, 2017. Revised: June 12, $2017 . \quad$ Accepted: June 18, 2017.

About the authors:

ROMANOVA VICTORYNA ANATOLEVNA graduated from the Moscow Mining Institute in 1960. She works in RUDN University (Peoples' Friendship University of Russia) since 1967. Associate Professor in Department of Architecture and Building. Scientific interests: computer-aided design of mechanisms, visualization of the processes of formation of analytical surfaces in the AutoCAD environment using a functional language AutoLISP.

ANAMARIA THOMA was born in Tirana, Republic of Albania. In 2010, she completed Peoples' Friendship University of Russia and received the bachelor's degree in "Architecture" in the same University. In 2012, she graduated from the magistracy with a degree in "Architecture". She is currently completing a master's degree in architecture and construction of multi-span spatial structures. Now she is writing a thesis on the topic "Analytical and numerical method of shells of the equal slope ramp on the elliptical plane". Area of scientific interests: architecture, landscape architecture, construction, interior design, modeling.

\section{For citation:}

Romanova V.A., Anamariya Thoma. (2017) Automatic modeling of the surfaces of the equal slope in Autocad system through language Autolisp. Structural Mechanics of Engineering Constructions and Buildings, No 5, 5 — 11, DOI: 10.22363/1815-5235-2017-5-5-11.

\section{С пи сокл л те ратуры}

1. Ancient Greek theatre. By Vlad. URL: https://www.thinglink.com/scene/471251280036102146

2. Museum of contemporary art (Niteroi, Brazil, architect Oscar Niemeyer)].

URL: https://www.adme.ru/tvorchestvo-dizajn/shedevry-sovremennoj-arhitektury566805/?page=3\#image27349615

3. Krivoshapko S.N., Ivanov V.N. Encyclopedia of Analytical Surfaces. - Springer International Publishing Switzerland, 2015, 752.

4. Krivoshapko S.N. Geometry and strength of general helicoidal shells. Applied Mechanics Reviews (USA). Vol. 52, No 5. - May 1999. 161-175. 
5. Иванов В.Н., Романова В.А. Конструкционные формы пространственных конструкций. Визуализация поверхностей в системах MathCad, AutoCad, - M.: Ассоциация строительных вузов, 2016.

6. Романова B.A. Образование циклических поверхностей с образующей окружностью переменного радиуса в Автокаде// Строительная механика инженерных конструкций и сооружений. - 2016. - № 3. - С. 20-24.

7. Романова В.А. Визуализация образования зонтичных поверхностей и поверхностей зонтичного типа с радиальными волнами, затухающими в центральной точке// Строительная механика инженерных конструкций и сооружений. - 2015. -№ 3.-С. 4-8.

\title{
АВТОМАТИЧЕСКОЕ МОДЕЛИРОВАНИЕ ПОВЕРХНОСТЕЙ ОДИНАКОВОГО СКАТА В СИСТЕМЕ AUTOCAD ПОСРЕДСТВОМ ЯЗЫКА AUTOLISP
}

\author{
РОМАНОВА В.А., ТХОМА АНАМАРИЯ \\ Российский университет дружбы народов, Москва, Россия
}

Графическое компьютерное моделирование - реальная возможность решения задач по образованию поверхностей кинематическим способом. Она обусловлена наличием систем автоматизированного конструирования, таких как MathCad, Mathematika, AиtoCad и др. Преимуществом системы АиtоСаd является наличие встроенного в нее функиионального языка AutoLisp. Располагая широким набором математических функций и функций для вычерчивания графических объектов, язык AutoLisp позволяет написать программу для вычерчивания оболочек любой сложности, в частном случае - оболочки одинакового ската на эллиптическом плане, с последующей передачей результатов в среду AutoCAD. Воспроизведение объектов в замедленном режиме дает возможность составлять мини-фильмы о формировании поверхностей. Изображение графических построений в трехмерном пространстве с использованием иветной палитры AиtoCAD усиливает выразительность изображения поверхностей и их элементов.

Целью исследования является возможность моделирования поверхности одинакового ската на эллиптическом плане, осуществляемая ее поэтапным вычерчиванием в замедленном динамическом режиме с созданием мини-фильма, позволяющего представить на экране монитора прочесс образования поверхности.

КЛЮЧЕВЫЕ СЛОВА: поверхность одинакового ската, моделирование, AutoLISP, AutoCAD, оболочка, форматирование, образующая, линейчатая поверхность, эллиптический план.

Поступила в редакиию 13 марта 2017 г. Прошла рецензирование 12 июня 2017 г. Принята к публикации 18 июня 2017 г.

Об авторах:

РОМАНОВА ВИКТОРИНА АНАТОЛЬЕВНА окончила Московский горный институт в 1960 году. С 1967 г. работает в Российском Университете дружбы народов. Доиент департамента Архитектуры и строительства. Область научных интересов: автоматизированное конструирование механизмов, визуализачия процессов образования аналитических поверхностей в среде AutoCAD с использованием функиионального языка AutoLisp, E-mail: v.a.r-victoryna@ mail.ru.

ТХОМА АНАМАРИЯ родилась в г. Тирана, Республика Албания. В 2010 году закончила бакалавриат Российского университета дружбы народов по направлению «Архитектура». В 2012 году окончила магистратуру по направлению «Архитектура». В настоящее время заканчивает магистратуру по направлению "Архитектура и строительство многопролетных пространственных конструкиий». Работает над диссертаиией по теме: «Аналитический и численный методы расчета оболочек одинакового ската на эллиптическом плане». Область научных интересов: архитектура, ландшафтная архитектура, строительство, интерьер, дизайн, моделирование.

\section{Для цитирования:}

Романова В.А., Тхома Анамария. Автоматическое моделирование поверхностей одинакового ската в системе AutoCad посредством языка AutoLisp// Строительная механика инженерных конструкций и сооружений. - 2017. - № 5. - С. 5 - 11, DOI: 10.22363/1815-5235-2017-5-5-11. 